RESEARCH ARTICLE

\title{
Mitigating the Implications of Covid-19 on the Academic Project at Walter Sisulu University in South Africa: A Proposed Framework for Emergency Remote Teaching and Learning
}

Rushiella N. Songca, ${ }^{\mathrm{i}}$ Clever Ndebele ${ }^{\mathrm{ii}}$ \& Munienge Mbodilaii

\section{Abstract}

Walter Sisulu University (WSU) in South Africa, like other universities worldwide, is faced with the challenges associated with the outbreak of the Covid-19 pandemic. The challenge has changed our day-to-day lives, including the way we interact and conduct business. In the midst of this, WSU has had to change the way learning and teaching occurs. Traditional face-to-face tuition had to be adapted by moving to the online mode of teaching and learning to both minimise the time lost in the academic project and protect staff and students from the devastating effects of the virus. This article reflects the actions taken by the University and describes its pilot-project approach to online learning and those processes it has put in place to ensure its effective implementation.

While it is accepted that switching to an online mode of teaching and learning can facilitate flexibility in space and time, the reality is that the majority of students at WSU - mainly due to their geographical and socio-economic environments - experience daily challenges ranging from poor network coverage, lack of internet connectivity, lack of electricity and other socio-economic impediments that make online learning stressful or beyond their reach. In this article, we present a model that could be used by higher education institutions (HEIs) to respond to Covid-19 in the short term. The proposed model is underpinned by a framework that caters for students who are readily able to access online learning, students with intermittent access to online facilities and finally, students who cannot access online education. First, we provide a brief description of online learning, highlighting the challenges presented to teaching and learning by this approach. We argue that our context and education policies present additional problems that militate against the adoption of online strategies by most HEIs. In the final instance, we present a framework that is better suited to our context and can be used during and after the lockdown. Data were collected using online questionnaires with both structured and openended questions from both lecturers and students to determine their experiences with the testing project. Lastly, we draw conclusions based on the findings of the study.

i Prof. Rushiella Nolundi Songca is the Vice-Chancellor and Principal at Walter Sisulu University, South Africa. ORCid: 0000-0002-2738-6615. Email: rsongca@wsu.ac.za

ii Prof. Clever Ndebele is Senior Director: Learning and Teaching at Walter Sisulu University, South Africa. ORCid: 0000-0002-4258-4812. Email: gcndebele@wsu.ac.za

iii Mr Munienge Mbodila is acting Head of Department, Information Technology Systems, Faculty of Economics \& Information Technology Systems at the Komani Campus of Walter Sisulu University, South Africa. ORCid: 0000-0003-4158-9037. Email: mmbodila@wsu.ac.za 


\section{Keywords}

Covid-19; emergency remote teaching; higher education; ICT; online learning; pilot project; rural universities; teaching and learning

\section{Introduction}

Walter Sisulu University (WSU), like all other contact universities in South Africa and the world, had to change its mode of teaching and learning following the outbreak of Covid-19. In South Africa, following the announcement of the nationwide lockdown level 5 by the President of the Republic on 26 March 2020, Higher Education Phase 1 response started, accompanied by an emergency planning phase for the sector (Council on Higher Education [CHE], 2020). At WSU, this planning phase was characterised by university management working to ensure that there were communication devices and access to data for students and staff, and by academic staff creating online material to be delivered to students.

As shown in the WSU 2020-2030 Draft Strategic Plan, before the Covid-19 pandemic, the University had adopted the blended learning approach as the delivery model for teaching and learning through the application of technology-enhanced pedagogies to address some of the key challenges in teaching and learning (WSU, 2020a). The outbreak of Covid-19 at the beginning of 2020 brought to the fore an urgent need for the University to implement alternative measures to deliver tuition. In the scramble to save the academic year and with insufficient time to plan and implement online learning, many institutions, including WSU, introduced what has now come to be described as emergency remote teaching and learning (Murphy, 2020; Hodges et al., 2020; CHE, 2020).

Some universities were able to adjust relatively smoothly to a multi-modal distance learning and teaching environment; but some have not been able to do so. As per WSU Term 2 Quarterly Report 2020,WSU fell into the latter category (WSU, 2020b). In response to the national initiatives, WSU adopted a primarily online and technology-infused tuition delivery model with a clear delivery plan intended to seamlessly replace the contact model. Under the contact model, which the institution is accredited to offer by the South African Department of Higher Education and Training (DHET), although a blended learning approach was adopted, the integration of technology in teaching and learning was very low before the advent of Covid 19. A technical task team was established in early April 2020 to develop online policies and other related guidelines. The team comprised academic and non-academic staff with experience in teaching online and information communication technology (ICT). This team was at the forefront of driving the online learning project at WSU. The team, which was inclusive of Deans, Campus Rectors, and other relevant staff members, met regularly to monitor progress and assess the implementation of agreed-upon interventions. The team approached the challenge by means of a pilot project, which this article describes and evaluates. This pilot project was intended to ensure the effective use of technology to aid teaching and learning at WSU.

The aim of this article is threefold. First, it discusses online teaching as an emergency resource during the pandemic and highlights the dynamics engendered by this model of teaching and learning. Secondly, we argue that our context and education policies present 
additional problems that militate against the adoption of online approaches by most universities in South Africa, especially historically disadvantaged universities such as WSU. In the final instance, we offer a framework that is best suited to the WSU context and could be used during and after the lockdown. The framework is drawn from our experience of the pilot project implemented to introduce online learning in response to the national lockdown resulting from the Covid-19 pandemic. Lastly, we draw conclusions based on the findings of the case study of the pilot project.

\section{Conceptual Framework}

Due to the outbreak of the Covid-19 pandemic, many institutions, including WSU, cancelled face-to-face (F2F) classes and moved all their courses online to continue teaching and learning while keeping both staff and students safe during periods of hard lockdown.

Globally, at the turn of the 21st century, many institutions started to use computers to teach online, and soon thereafter, eLearning was adopted to characterise the use of technologies, specifically computers and the internet (Sangra et al., 2012; Lauran et al., 2012; El-Seoud et al., 2014) to teach.

During the pandemic, many schools and universities closed to keep students and teachers safe and adopted online multi-modal models to teach in order to continue teaching and learning. As a result, distance learning, remote learning and eLearning approaches have taken centre stage during the pandemic and have been adopted by many institutions in varying degrees (Williamson et al., 2020).

\section{Online learning}

Online learning characterises 21st-century educational systems. As it entails the provisioning of programmes to students separated by distance, some researchers argue that it evolved from distance learning (Sangra et al., 2012). Initially, eLearning was understood to refer to education mediated through computers and the internet. Initially terms such as 'computer-based learning', 'computer-training', 'technology-based learning' were used before being replaced by eLearning. Recently, the term 'online learning' has gained more traction (Sangra et al., 2012).

Online learning is difficult to define. Research reveals that online learning has no single definition, and the original definition has since been expanded to include anything delivered, enabled or mediated by electronic technology for the explicit purpose of learning (Li \& Masters, 2009; El-Seoud et al., 2014). Li and Masters (2009, p. 246) argue that the ' $\mathrm{e}$ ' in eLearning is not only about electronics but should be understood to encapsulate the distinguishing characteristics of eLearning namely, "evolving, enhanced, everywhere, every time and everybody". The change in the conceptualisation and application of eLearning has resulted in the adoption of online learning as a substitute for eLearning. The latter reflects the multi-media nature of learning inclusive of the use of social media and communication platforms such as WhatsApp, Facebook and others (Ramakrisnan et al., 2012). For the purposes of this article, online learning and eLearning - as defined by Li and Masters (2009) - are used interchangeably. 
Online instruction is less personal than F2F because of a lack of physical proximity between the learner and the teacher; therefore teachers are expected to employ techniques to make the classroom more interactive to motivate the students (El-Seoud et al., 2014). To be successful, teaching online requires online instructor readiness and their ability to be flexible and adapt to formal and less formal teaching methods (El-Seoud et al., 2014). Moreover, successful online teaching requires varied approaches relating to delivery and feedback on assessment and the instructors' continued presence online (Roddy \& Lodge, 2017; Tanis, 2020).

According to Luaran et al. (2014), online learning is referred to as a learning system that maximises the use of hardware and technologies and occurs online synchronously or offline asynchronously. Interactions vary and include interactions between learnerinstructor, learner-content and learner-learner (Ramakrisnan et al., 2012; El-Seoud et al., 2014; Roddy \& Lodge, 2017; Tanis, 2020).

Online support is critical to students' learning and comes in a variety of channels such as chat rooms, e-mails, e-tutors. It provides students with answers to specific questions and enhances their understanding of a given task or content (Ramakrisnan et al., 2012; Luaran et al., 2012). Online learning, unlike emergency remote teaching (ERT), is a carefully designed process that has distinctive pedagogical dimensions such as modality, the role of online assessment and the role of the instructor (Hodges et al., 2020). Online learning also requires an effective eco-system of learner support to ensure that learners are adapting to novel ways of teaching and learning and receive the necessary support to do so. However, in most instances, these types of support initiatives take time to identify and build which is not always possible in the case of an emergency such as the one we currently face.

Online learning is often designed purposely to be remote and distant; it is accessible and voluntary and unlike ERT not urgent and has the full support of the Faculty and students (University of the People, 2020). Planning, developing and preparing a fully online course can take six to nine months before the course is delivered (Hodges et al., 2020).

\section{Emergency remote teaching}

The pandemic created a situation where we did not have the luxury of time to develop online learning as described above. In response we turned to ERT which by its nature facilitates swift response time and rapid implementation. ERT occurs when there is a departure, albeit temporarily, from the traditional mode of learning. When this shift occurs, F2F teaching is flipped or turned into digital education (University of the People, 2020; Hodges et al., 2020).

ERT is precipitated by a crisis that prevents traditional F2F teaching from taking place. Consequently, when this occurs alternative learning models such as online lessons, radio lessons, and blended learning may have to be introduced as temporary emergency measures to ensure that learning continues (University of the People 2020; Hodges et al., 2020).

ERT provides temporary access to instruction and provides lecturers with an opportunity to be creative and innovative. However, implementation of ERT in various countries, including South Africa, presents challenges to both students and lecturers alike. A study of the impact of eLearning amongst nursing students and teachers in Nepal 
(Sudedi et al., 2020) revealed that institutions in many parts of the world, including those in South Africa, grapple with similar problems. For example, teachers and students face difficulties when studying or teaching at home. Moreover, socio-economic conditions and technological skills or lack thereof may act as hindrances to the eLearning process. The Nepalese study and experiences encountered at WSU revealed that some students and lecturers had to be trained in the use of technology before they could work online.

Many lecturers may find the process of teaching online stressful because they were suddenly expected to traverse unfamiliar territory (Morgan, 2020). This was also the case at WSU.The adoption (often in a rapid manner) can result in lecturers and students claiming that they are practising online teaching and learning although this assertion is inaccurate because there are clear differences between ERT and online teaching, not least of which relate to the time taken to prepare for and implement full-scale online learning (University of the People, 2020; Hodges et al., 2020). WSU has support staff who train both academics and students to teach and learn online. However, with the move to online and increased demand for support, these support teams may be unable to deal with the increased demand as will be shown in the results' section of this article. Before Covid-19 descended upon us, very few academics at WSU were taking up the training, and those who did often needed re-training because they never actually taught digitally in practice due to a lack of access to technological tools. The Nepal study revealed similar challenges (Sudedi et al., 2020).

The success of remote teaching and learning also hinges on the ability to use a learning management system (LMS) and the reliability of those systems. Universities located in rural areas such as WSU have to contend with weak internet service and low bandwidth internet. Even those with high bandwidth internet have to deal with service interruptions or services slowing down due to collective consumption as more people use internet at home and work during the lockdown (Sudedi et al., 2020; Williamson et al., 2020). These challenges are disruptive and have a negative impact on remote teaching. Therefore, institutions have to be innovative and flexible.

According to Williamson, Eynon and Porter (2020), not all young people are necessarily digitally savvy or 'digital natives'. The use of technology is multidimensional and in as much as young people can use technologies a critical minority of young people is excluded entirely (see Williamson et al., 2020). Some students at WSU, for example, expressed their inability to navigate the LMS and unfamiliarity working with a laptop and learning online.

In addition, although WSU was at the forefront amongst historically disadvantaged universities in providing laptops and data access to students as shown in the case study below, nonetheless socio-economic factors and other challenges faced by students threatened to undermine these interventions.

\section{The Case Study}

The setting of this case study is the South African higher education system, where there are great levels of inequality between institutions due to their differing geographic locations, levels of resourcing, cultural, racial and political histories (Leibowitz et al., 2015; Leibowitz et al., 2017). Under apartheid and colonialism, social inequalities were embedded and 
reflected in all spheres of social life, including the higher education system as a product of the systemic exclusion of blacks and women (Badat, 2010). Badat further argues that this differentiation and diversification along lines of race and ethnicity, resulted in the advantaging in various ways of the historically white institutions and the disadvantaging of the historically black institutions.

Even after twenty-six years of democracy, the remnants of apartheid remain and student experiences in historically black universities (located predominantly in rural areas) are undesirable because of isolation, neglect and poor resource provisioning (HSRC, 2005; Ndebele et al., 2017). Thus, Leibowitz et al. (2017, p. 30) aver:

In the South African context, history and geography intersect: whether a university was 'previously disadvantaged' and continues to be under-resourced; and whether its physical location affects the institution's ability to attract and retain academic staff, and in this way, impacts on teaching quality.

Given its rural location, this case study shows that where WSU is located presents on the one hand an opportunity for the use of online formats in the delivery of teaching and learning to compensate for geographic isolation; on the other hand, there is often the challenge of technical and professional support for the smooth operation of online platforms (Mollenkopf, 2009; Ndebele et al., 2016).

WSU was established on 1 July 2005 through a merger of two polytechnics and a university, i.e. the former Border Technikon, Eastern Cape Technikon and University of Transkei in terms of the Higher Education Act 101 of 1997, as amended. WSU operates under a divisional governance and management system and has four campuses, each headed by a Campus Rector. The four campuses are spread across four distant locations in the Eastern Cape province of South Africa, namely in Mthatha, Butterworth, Buffalo City and Komani (formerly Queenstown). The Mthatha Campus, which comprises five faculties, is composed of three delivery sites, namely: Nelson Mandela Drive Site, Zamukulungisa Heights Site and Nkululekweni Site. Butterworth Campus, consisting of three faculties is only one delivery site. The Buffalo City Campus consists of three faculties and comprises six delivery sites spread across the city of East London, namely: Cambridge Street Site; Buffalo City Stadium Site; Heritage Building Site; College Street Site; Chiselhurst Site and Potsdam Site. Komani campus with two faculties has two delivery sites, namely: Whittlesea Site and Grey Street Site.

The University is currently in the process of finalising its next strategic plan 2020-2030 (WSU, 2020a) and underpinning the new strategic plan. The following draft new vision 2030 has been crafted in which WSU is to be a "value-driven, technology-infused African university providing a gateway for local talent to be globally competitive and make a sustainable socio-economic impact."

To realise the vision, the mission of the University is as follows: "Through quality teaching and learning, innovative research and community engagement, WSU inspires future-ready graduates to become responsible citizens who are able to address complex societal challenges in critical, ethical, scholarly, sustainable and entrepreneurial ways." 
Inspired by the liberation struggle stalwart Walter Sisulu after whom the University is named, and guided by our country's foundational norms, the University accepts as its core values: academic freedom; honesty and integrity; quality and excellence; dignified, ubuntubotho-led behaviour; incorporating respect for oneself, other persons and property; and humility, selflessness and service orientation.

The student enrolment at WSU has increased from a total of almost 26000 student headcounts in 2015 to just above 33000 in 2019. Women account for 56\% of the student body, and $99 \%$ of the student population are black Africans. The University draws most of its students from high schools located in the Eastern Cape, a province considered to be one of the poorest in the country. The majority of students enrolled at WSU (88\%) are from traditionally disadvantaged backgrounds (WSU, 2020a).

Prior to Covid-19, WSU used Blackboard as the LMS which means that there was a system in place for blended teaching and learning as well as to share information and communicate with students. On 7 August 2018, WSU announced the Blackboard Mobile App and Blackboard Collaborate Tool as additional tools to the course management system which made blended teaching and learning, interaction and communication with students more all-in-one. The potential benefits of Blackboard include: (i) increased availability, (ii) quick feedback, (iii) improved communication, (iv) tracking, and (v) skill building (Bradford et al., 2007). However, the majority of lecturers at WSU were not fully utilising the tools to enhance teaching and learning. Challenges such as technology adoption, skills, connectivity, network coverage, tools of trade and many more were amongst the major obstacles for many academics and students to make full use of the LMS. The online presence prior Covid-19 was made of only a few groups of academics, who in our context are called eLearning champions. To overcome this, a multi-modal approach was proposed and piloted phases presented in the following section.

\section{Case study phases}

The multi-modal approach at WSU, under the five lockdown levels, is represented diagrammatically in Figure 1 below.

\begin{tabular}{|c|c|c|c|c|}
\hline $\begin{array}{l}\text { PHASE } 1 \\
\text { Lockdown Level } 5\end{array}$ & $\begin{array}{l}\text { PHASE } 2 \\
\text { Lockdown Level } 4\end{array}$ & $\begin{array}{l}\text { PHASE } 3 \\
\text { Lockdown Level } 3\end{array}$ & $\begin{array}{l}\text { PHASE } 4 \\
\text { Lockdown Level } 2\end{array}$ & $\begin{array}{l}\text { PHASE } 5 \\
\text { Lockdown Level } 1\end{array}$ \\
\hline $\begin{array}{l}\text { - Needs assessment } \\
\text { for online learning. } \\
\text { - Senate approval of } \\
\text { Emergency Teaching } \\
\text { and Learning Plan. }\end{array}$ & $\begin{array}{l}\text { - Pilot testing for } \\
\text { remote learning. } \\
\text { - Asynchronous } \\
\text { learning continues for } \\
\text { all students. } \\
\text { - University academic } \\
\text { calendar amendment. } \\
\text { - Remote learning } \\
\text { continues. }\end{array}$ & $\begin{array}{l}\text { - Distribution of } \\
\text { laptops and loading } \\
\text { of data for students. } \\
\text { - Decision to delay } \\
\text { return of students } \\
\text { until beginning of } \\
\text { September. } \\
\text { - Remote learning } \\
\text { continues. }\end{array}$ & $\begin{array}{l}\text { - Preparations for } \\
\text { return of } 50 \% \text { of the } \\
\text { students. }\end{array}$ & $\begin{array}{l}\text { - Hundred per cent of } \\
\text { the students return. } \\
\text { - Online learning } \\
\text { continues with } \\
\text { restricted F2F contact } \\
\text { only for practical } \\
\text { subjects. } \\
\text { - Collection of } \\
\text { laptops continues for } \\
\text { those students who } \\
\text { could not be reached } \\
\text { during levels } 2,3 \\
\text { and } 4 \text {. } \\
\text { - Implementation } \\
\text { of alternative } \\
\text { assessment where } \\
\text { necessary. }\end{array}$ \\
\hline
\end{tabular}

Figure 1: Summary of the phases of the online multi-modal teaching approach 


\section{Phase 1: Lockdown Level 5, March/April 2020}

Following the lockdown pronouncement at the end of March 2020, an emergency multi-modal teaching plan was developed and approved by the Senate. Thereafter, various policies and procedures on remote learning such as 'Quality Standards for Online Learning, Guidelines for Online Assessments' and 'WSU New Approach to Teaching and Learning During Covid-19' were developed. This was followed by a communiqué to all Deans requesting them to indicate laptop needs for all staff. Four hundred academics out of approximately eight hundred and fifty stated that they did not have laptops. Procurement of laptops for all academics, including part-time academics, commenced. Simultaneously, a survey was sent to all students to determine their online learning device needs. $87 \%$ indicated that they needed laptops for learning and teaching. A decision was taken to issue all academics with $10 \mathrm{~GB}$ of data and all students with $30 \mathrm{~GB}$ of data, $10 \mathrm{~GB}$ during daytime and $20 \mathrm{~GB}$ at night. Following DHET communication on funding of laptops for students funded by the National Student Financial Aid Scheme (NSFAS), the University procured 21000 laptops and commenced distributing these to students at their homes using various service providers. The distribution of laptops commenced in mid-June 2020 and continued until August 2020 throughout the country using both courier companies and the University's own transport department. Students who could not be reached for any reason collected their laptops when they arrived on campus when the country moved to lockdown level 1.

To prepare for the roll-out of ERT, a decision was taken to pilot online learning, to test the readiness, effectiveness and the usability of the learning model and the related systems to achieve effective and efficient learning and teaching. A sample size of 500 students was selected from four campuses of WSU. A consent form and a pre-testing and post-testing questionnaire were designed. Specific objectives of the pilot testing were defined as follows:

(i) Examine the extent to which, in the opinion of both lecturers and the students, the training offered to lecturers has enabled them to deliver lectures online competently. In other words, are lecturers able to, for example, competently record lectures, upload recorded lessons and study materials to LMS, and share the link to the lectures with students?

(ii) Assess lecturers' ability to competently conduct 'live' online lectures. In other words, are lecturers able to log in to the online platform, invite students to join the forum, share documents 'live' during lectures, and stimulate interaction with students during online lectures?

(iii) Determine students' actual access to study materials loaded on LMS or couriered physically (for those on 'distance learning' mode of delivery). In other words, are students able to access study materials on time?

(iv) Evaluate students' participation efficacy in terms of their ability to log in to join 'live' lectures, hear the lecturer clearly, and interact with the lecturer during an online lecture.

(v) Examine students' and lecturers' levels of satisfaction with the quality of 'help' received from support staff, such as ICT and faculty office. 
The results of the pilot exercise are presented in the next section. It is worth noting that because so many students (and many academics) did not have access to computers and data off-campus, the previous use of the LMS or any other form of online learning was minimal. This is unlike at historically advantaged universities where data and laptops may have been more readily available to staff and students. In these institutions, the shift under Covid-19 was mainly an increase in their online presence and maybe involved consideration of issues of student engagement and online assessment. While this may all be complicated, it is nowhere close to the WSU experience.

To prepare for both the testing and the eventual rollout of online learning and teaching, massive training of staff was conducted on the use of the LMS on aspects such as uploading of learning materials for students to access and the population of module sites. Asynchronous instruction proved to be preferable to synchronous activities, especially for under-digitised students. Given our context and the fact that our self-hosted Blackboard LMS was struggling to cope with the demand, lecturers were advised to use Microsoft Teams and other platforms. This meant that academics also had to be trained in the use of these alternative platforms. Therefore, teams of academic 'experts' in the different faculties were established to assist other lecturers who were struggling with the use of these alternative teaching platforms. It soon became clear that the support interventions had to be enhanced. These teams also collaborated across faculties and began to share ideas and best practices.

\section{Phase 2: Lockdown Level 4, May/June 2020}

To ensure a smooth pilot stage, Tablets were distributed to the 500 students and data loaded for the pre-testing pilot on the students' cell phone numbers. A pre-testing questionnaire was sent to the students together with the tablets to assess their readiness in terms of devices, network coverage, internet access, location and other challenges that may affect their participation in the online infused teaching and learning. After the testing, a posttesting questionnaire was sent to both students and lecturers to determine the levels of satisfaction as well as to measure whether the pilot addressed the objective of the testing.

The pilot testing phase was conducted during June 2020 with regular weekly feedback timelines to allow the expeditious initiation of corrective measures as well as a postimplementation review. According to Welman and Kruger (1999), the value of a pilot study is to determine possible flaws in measurement procedure, identify unclear items in a project as well as the behaviour of the participants about any discomfort experienced concerning an item in a questionnaire. In their research, Lee, Whitehead, Jacques and Julious (2014) agreed that the primary goal of a pilot is to offer adequate assurance to permit a big definitive test to be undertaken. The testing process was scientifically and academically sound, addressing key points of strategic implications to achieve a clear and coordinated selection process, implementation plan as well as clear definition of testing units. The actual pilot testing process occurred over four weeks, and in Figure 2 are the weekly processes involved during the testing. 


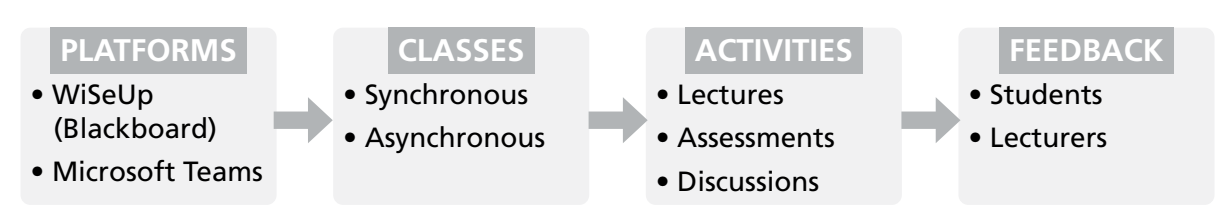

Figure 2: Weekly processes involved during the testing

- Platforms: Online access for teaching and learning during the testing, WiSeUp (Blackboard) was used as the primary LMS and Microsoft Teams as an additional eLearning platform to leverage online teaching.

- Classes: During the testing classes were conducted in both synchronised and unsynchronised online delivery mode and a standard timetable was used to avoid clashes.

- Activities: Besides regular lectures, students were given weekly tasks such as assessments, quizzes as well as participation in discussion groups.

- Feedback: To observe students' and lecturers' levels of satisfaction during the testing, a weekly survey was conducted using an online questionnaire.

While the testing was taking place, to salvage the academic year, a decision was taken to commence with asynchronous learning for the rest of the student population where students were sent materials by academics through various platforms such as the LMS, WhatsApp, Microsoft Teams and Google docs to mention a few.

\section{A synopsis of the testing pilot results}

The responses of the testing pilot from the four campuses are presented in this section according to the critical objectives of the testing. Table 1 shows the number of participants per campus according to their Faculty.

The pilot testing was conducted over four weeks, and data were collected using online questionnaires with both structured and open-ended questions from both lecturers and students to determine their experiences with the testing project. The presented results respond to the primary keys objectives of the testing pilot.

One of the objectives of the pilot was to ascertain the extent to which training provided in the University enabled lecturers to deliver online lectures, for example, competently record lectures, upload recorded lessons and study materials to LMS, and share the link to the lessons with students. Most lecturer participants from all the campuses indicated that training enabled them to deliver online classes as well as uploading of learner guides, study materials and other supporting material in the LMS. Some of them were even able to upload videos, YouTube links, and voice-over PowerPoint. This preliminary result goes along with other studies that show that training is one of the factors that needs to be considered by an institution before the implementation of eLearning (Mbodila et al., 2019; Shamase, 2016; Vale, 2016; Arden, 2014). According to Mbodila et al. (2019), staff training is a fundamental factor that equips them with essential technological and pedagogical skills related to ICT use in learning and teaching. 
Table 1: Number of participants per campus

\begin{tabular}{|c|c|c|c|}
\hline Campus & Faculty & $\begin{array}{l}\text { Number of } \\
\text { participants }\end{array}$ & Level of study \\
\hline \multirow[t]{3}{*}{ Mthatha } & $\begin{array}{l}\text { Faculty of } \\
\text { Commerce and } \\
\text { Administration } \\
\text { (FCA) }\end{array}$ & 75 & $\begin{array}{l}\text { Level } 1=25 \\
\text { Level } 2=25 \\
\text { Level } 3=25\end{array}$ \\
\hline & $\begin{array}{l}\text { Faculty of Natural } \\
\text { Sciences (FNS) }\end{array}$ & 35 & $\begin{array}{l}\text { Level } 1=15 \\
\text { Level } 2=10 \\
\text { Level } 3=10\end{array}$ \\
\hline & $\begin{array}{l}\text { Faculty of } \\
\text { Educational } \\
\text { Sciences (FEDS) }\end{array}$ & 35 & $\begin{array}{l}\text { Level } 1=15 \\
\text { Level } 2=10 \\
\text { Level } 3=10\end{array}$ \\
\hline \multirow[t]{2}{*}{ Butterworth } & $\begin{array}{l}\text { Faculty of } \\
\text { Education Science } \\
\text { (FED) }\end{array}$ & 45 & $\begin{array}{l}\text { Level } 1=25 \\
\text { Level } 2=10 \\
\text { Level } 3=10\end{array}$ \\
\hline & $\begin{array}{l}\text { Faculty of } \\
\text { Engineering and } \\
\text { Technology }\end{array}$ & 59 & $\begin{array}{l}\text { Level } 1=29 \\
\text { Level } 2=15 \\
\text { Level } 3=15\end{array}$ \\
\hline Buffalo City & $\begin{array}{l}\text { Faculty of Science, } \\
\text { Engineering and } \\
\text { Technology (FSET) }\end{array}$ & 125 & $\begin{array}{l}\text { Level } 1=45 \\
\text { Level } 2=40 \\
\text { Level } 3=40\end{array}$ \\
\hline \multirow[t]{2}{*}{ Komani } & $\begin{array}{l}\text { Faculty of } \\
\text { Education } \\
\text { and School } \\
\text { Improvement } \\
\text { (FEDSI) }\end{array}$ & 60 & $\begin{array}{l}\text { Level } 1=20 \\
\text { Level } 2=20 \\
\text { Level } 3=20\end{array}$ \\
\hline & $\begin{array}{l}\text { Faculty of } \\
\text { Economics and } \\
\text { Information } \\
\text { Systems (FEITS) }\end{array}$ & 20 & $\begin{array}{l}\text { Level } 1=10 \\
\text { Level } 2=5 \\
\text { Level } 3=5\end{array}$ \\
\hline Lecturers & & 38 & \\
\hline Online tutors & & 46 & \\
\hline Total & & 538 & \\
\hline
\end{tabular}

The study also sought to identify any challenges lecturers and students experienced concerning logging into the online platform, inviting students to join the forum, sharing documents 'live' during lectures, and stimulating interaction with students during online lectures. Both lecturers and student participants reported that they were able to access the online platform, download, and share study materials effectively. Participants also indicated that they used various platforms for sharing and conducting live classes; however, most students were using the LMS (WiSeUp) to download study material that was zero-rated by various mobile services. Lecturers and students also indicated that Microsoft Team was the platform most frequently used for synchronous, live classes. Figure 3 shows the platforms that were mostly used during the testing pilot. 


\section{Synchronous Online Platforms}

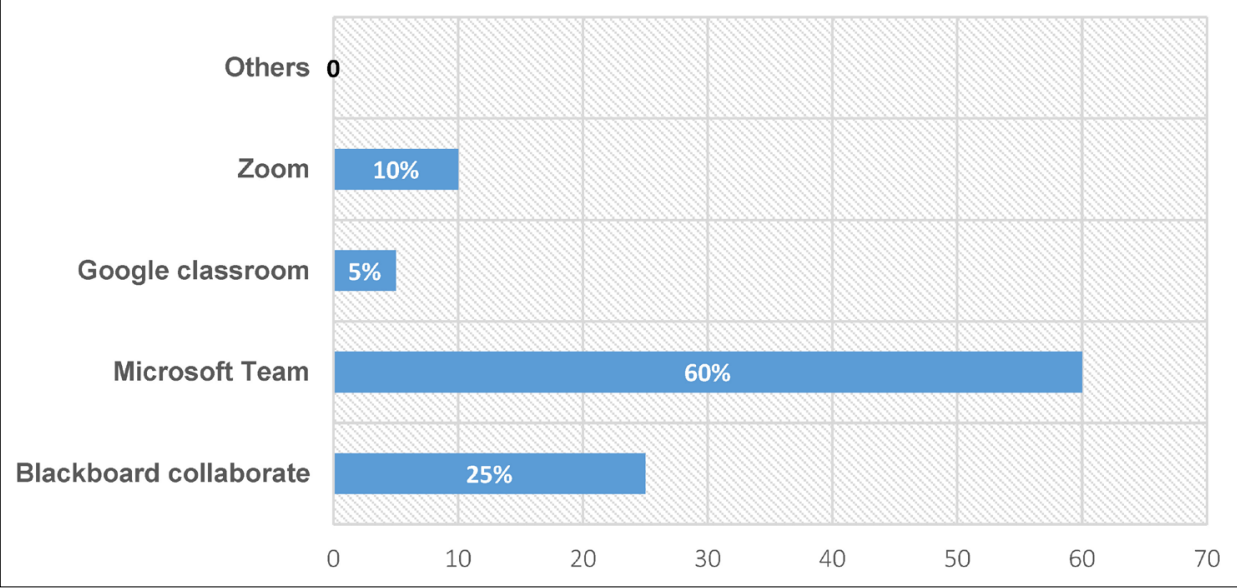

Figure 3: Online platforms for synchronous class $(\mathrm{N}=492)$

On a question as to whether or not students were able to access study materials on time, students indicated that they were able to access learning materials. However, with the challenge of the connectivity, not all of them managed to get such materials on time or participate in all the synchronous classes. This challenge is because most WSU students are located in rural areas where the network connectivity is poor which caused problems for live streaming as well as downloading or uploading materials. This shows that WSU in South Africa, like universities in other developing countries, grapples with infrastructural inequalities (see Subedi et al., 2020, p. 70; Williamson et al., 2020, p. 110). Although people may have internet access, people in city centres often enjoy faster internet compared to those living in rural areas (see Sudedi et al., 2020).

Similarly, when asked if they were able to log in to join 'live' lectures, hear the lecturer clearly, and interact with the lecturer during online lessons, the participants indicated that the internet connection was a challenge most of the time during synchronous classes. Hence, they had experienced challenges in joining live lectures, hearing the lecturers clearly while interacting with the rest of the class. The issue of network coverage in certain parts of South Africa, particularly in the rural areas in the Eastern Cape province, is still a significant delaying aspect in rolling out online teaching and learning at WSU. Students' home environments as shown in this case study presented obstacles for students studying from home during the lockdown. Some students live in small households with their siblings and extended family members. These experiences further militate against participation in synchronous learning for students living in these circumstances. In addition, young people who do not ordinarily have digital access in their homes are likely to have fewer digital skills and this may undermine their ability to learn effectively (see also Williamson et al., 2020).

The quality of internet access presents real challenges for students in rural South African universities such as WSU as well as the University of Fort Hare, University of 
Limpopo, University of Venda and the University of Zululand. To address this, most lecturers used asynchronous approaches for teaching to allow students to access study materials at a convenient time, and they adopted multi-modal pathways such as video recorded mini-lessons and made use of social media and communication platforms such as WhatsApp (see also Morgan, 2020, p. 137).

A standard Likert scale was used to determine the extent to which both students and lecturers were satisfied with the quality of 'help' received from support staff, such as ICT and faculty offices. Participants selected responses which ranged from 5 , indicating strongly agreeing to 0 indicating strongly disagreeing with the statements given. Figures 4 and 5 illustrate the responses of students and lecturers, respectively.

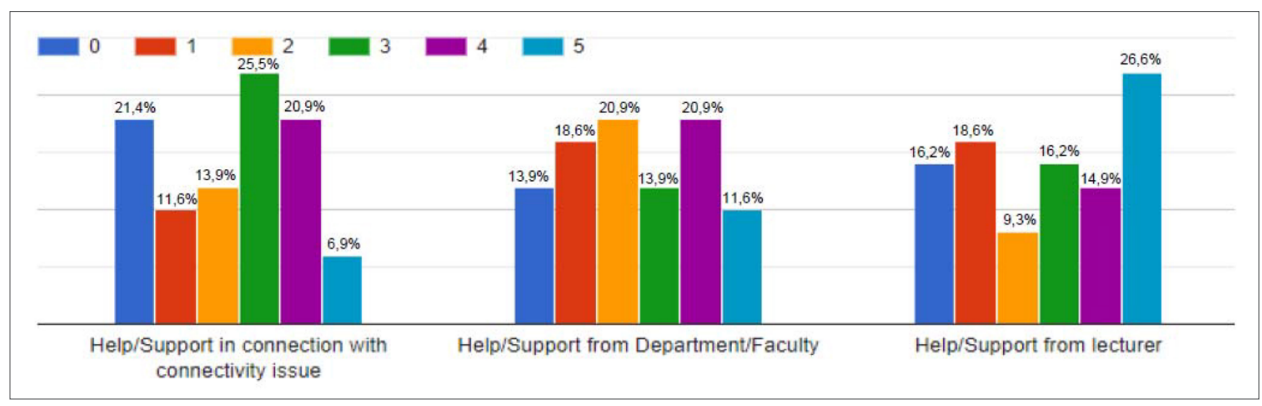

Figure 4: Students' overall satisfaction with the quality of help $(\mathrm{N}=454)$

Figure 4 shows that $54 \%$ of the students found the support they received in connection with connectivity issues either fair, agreed or strongly agreed that support was adequate, while $46 \%$ either did not receive any support at all, disagreed or strongly disagreed that there was any support. The fact that almost half the respondents were dissatisfied with ICT support was cause for concern.

Concerning support from the Faculty, specifically the Head of Department or the Dean, $46 \%$ of the respondents found such support either fair, agreed that they received enough support, or strongly agreed that support was adequate. In comparison, 54\% either did not receive any support at all, disagreed or strongly disagreed that there was any support. Again, the fact that more than half of the students did not receive any support at all is cause for concern.

A further question sought to find out student satisfaction with support from the lecturers. 58\% found such support either fair, agreed that they received enough support or strongly agreed that support was adequate while $42 \%$ either did not receive any support at all, disagreed or strongly disagreed that there was any support. It would have been expected that at least more support would have been received from the lecturers who interacted with students daily online. To mitigate these challenges, a call centre was established in the University with a dedicated operator from each Faculty responsible for receiving all student queries. The call centre also has representative operators from support functions such as the teaching and learning centre, student affairs and the ICT department. This is expected 
to help improve student support as the University moves to level 2 of the lockdown. It should be noted that all of these decisions had to be made against a backdrop of significant institutional financial constraints. A standard Likert scale questionnaire with a scale ranging from 1 to 5 and not applicable (N/A) was used to determine lecturers' satisfaction with the quality of 'help' received from support staff, such as ICT and faculty offices: $1=$ very dissatisfied; 2 = dissatisfied; 3 = neither dissatisfied nor satisifed; $4=$ satisfied; 5 = very satisfied; and $\mathrm{N} / \mathrm{A}=$ not seeking such help.

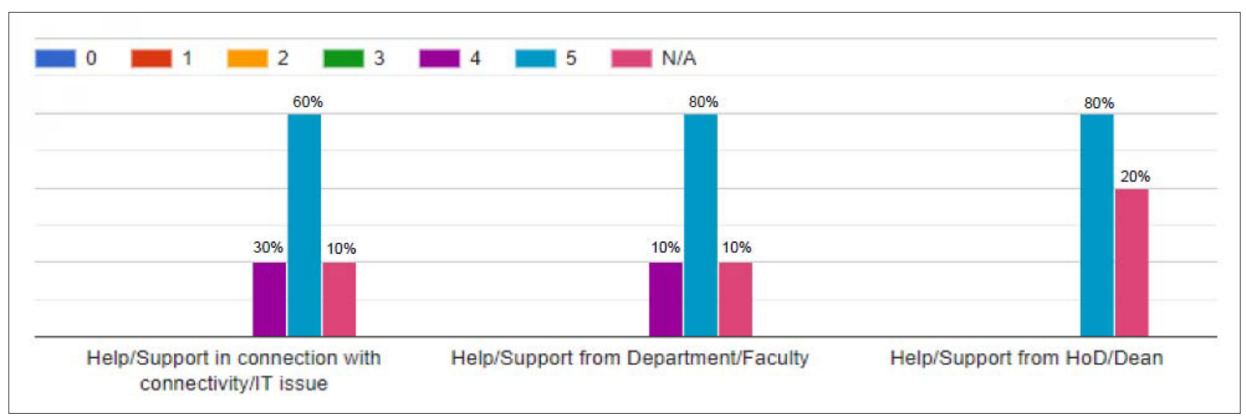

Figure 5: Lecturers' overall satisfaction with the quality of help $(\mathrm{N}=38)$

Concerning lecturer satisfaction with connectivity issues, $90 \%$ of the lecturers who responded to the question found the support satisfactory by either agreeing or strongly agreeing that support was adequate (10\% indicated not applicable to the question). With regard to support from the Faculty, specifically the Heads of Departments, again the vast majority either agreed or strongly agreed that support was adequate (90\%) while 10\% indicated that the question was not applicable to them. A further question that sought to find out lecturer satisfaction with support from the Dean revealed that $80 \%$ of the lecturers either agreed or strongly agreed that support was adequate. The positive feedback from the lecturers could be attributed to the fact that in preparation for ERT the University issued laptops and data cards to academics and academic support staff who directly support online learning. In order to mitigate challenges experienced by lecturers in the faculties, academics who are experts in eLearning were identified as champions in their respective departments so that they could assist other lecturers experiencing challenges. In addition, lecturers could also use the call centre. This is expected to help improve student support as the university moves to level 2 of the lockdown.

\section{Phase 3: Lockdown Level 3, June/July/August 2020}

Armed with the results from the testing phase, and some of the intervention measures discussed above, the 29 June 2020 was set as the roll-out date for online learning to all students. A continuous reflective questionnaire was developed for online learning to enable continuous feedback from both lecturers and students during the roll-out. The university calendar was adjusted to end in February 2021. While laptops had been procured for funded students as this would be recouped from their grants and bursaries, debate on unfunded students in light of the "no student to be left behind" principle continued. The Students' 
Representative Council argued that if no student was to be left out of the online learning and teaching process as indicated by the Minster of Higher Education and Training, then all students needed to be issued with laptops regardless of funding source. A resolution was eventually reached to issue laptops to all students who had requested them regardless of funding. Due to the dispersed geographical location of students throughout the country, challenges concerning the distribution of laptops soon emerged. The main challenges in the delivery process were inadequate, incomplete, unverifiable or incorrect contact details, especially physical addresses and phone numbers, supplied by students despite a request made to them through an online survey to update their details on the university system. For example, some students had a postal box address in rural areas without a physical address. Another challenge was the issue of students registering their parents' contact details (e.g. cell phone numbers) on registration forms instead of their own numbers. To mitigate the challenges, ICT at WSU developed an App called WSU website mobile verify to verify student and staff details. This application assisted students to update their information by including contact and address details. The issue of network connectivity also continued to affect many students.

\section{Phase 4: Lockdown Level 2, August/September 2020}

Level 2 lockdown triggered preparation for the return of students from 24 August 2020. This date was brought forward from the originally set date of 2 September 2020 for those faculties and campuses that felt ready. During deliberations at Senate, some campuses and faculties indicated that they were ready in terms of the Covid-19 health and safety protocols to accept students and were therefore given the green light to so. Online learning continued with students only accessing facilities such as residences, library, and laboratories but accessing tuition from their residences. F2F tuition commenced under strict social distancing conditions only for students involved in practical subjects for which it is not possible to learn remotely.

\section{Phase 5: Lockdown Level 1, September/October 2020}

Lockdown level 1 saw preparations for and the return of all students. A cautious approach was adopted where initially online learning continued with restricted F2F contact only for practical subjects. This was gradually relaxed with F2F allowed in venues with numbers as stipulated by the National Coronavirus Command Council. Collection of laptops continued for those students who could not be reached during levels 2, 3 and 4 . Implementation of alternative assessment was adopted where necessary to replace the traditional sit-down examinations. Following the upsurge in Covid-19 cases towards the end of November 2020 in the Eastern Cape Province, all F2F tuition was suspended again in favour of online learning. Online learning is set to continue when the 2021 academic year commences.

\section{Proposed Framework for Online Intervention}

The Covid-19 emergency has precipitated a much wider uptake of educational technology in the University, which had not been widespread prior to 2020. The benefits of such 
use are undoubted and is one of the few 'silver linings' of the pandemic in our context. Resistance to technology or lack of access to hardware, bandwidth and EdTech proficiency had been at the heart of the low number of courses with an online presence prior to 2020, but the pandemic forced the institution's hand in this regard and the achievement of the goal of blended learning will undoubtedly continue if and when WSU returns to contact classes for all in 2021 or beyond. A resolution has already been reached by the Institutional Management Committee that at the resumption of the 2021 academic year online learning will continue. Processes are already under way to procure 7200 laptops for the anticipated 2021 first-year intake.

As part of our recommendations, we present in Figure 6 a framework that can inform future long-term interventions while providing both students and staff an effective online education.

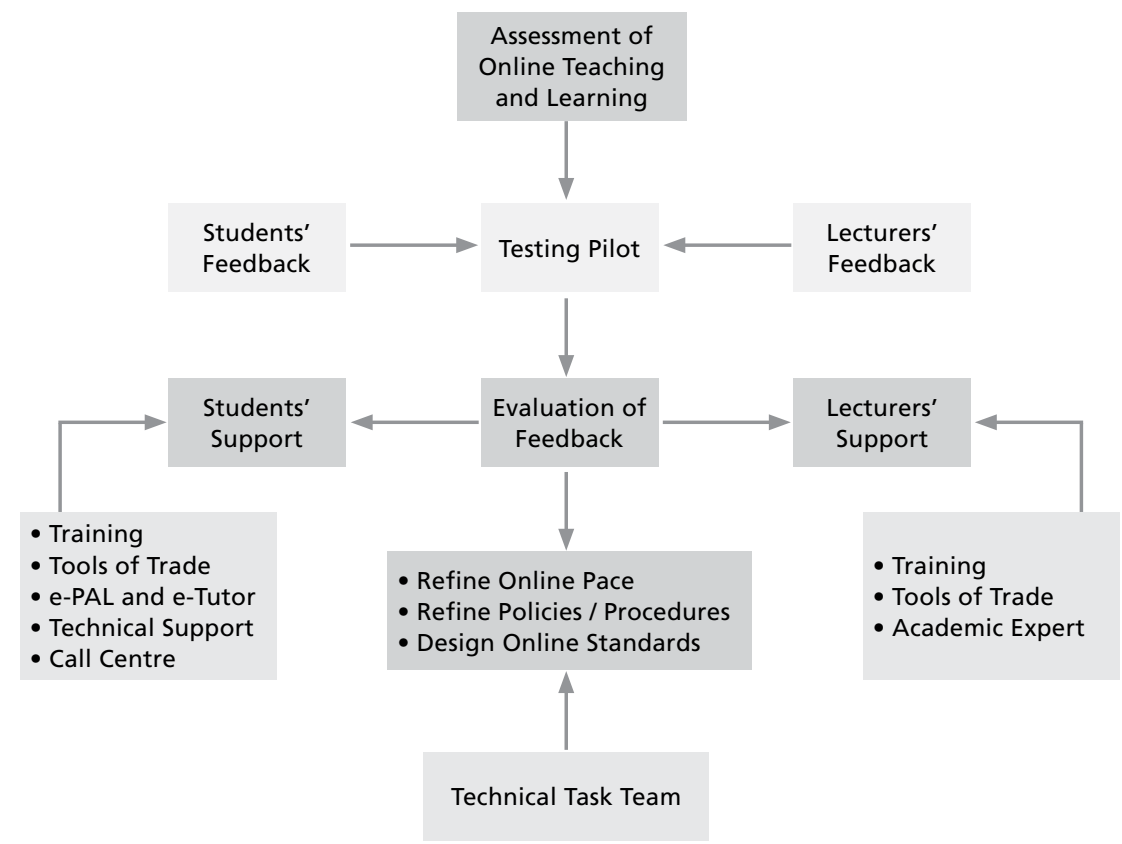

Figure 6: Proposed framework for online intervention

- Training of students, more specifically students registered with WSU for the first time, should be compulsory. Training should include sessions on how to use the LMS system. At a strategic level, the use of technologies should be integrated in the teaching and learning ecosystem of education. Most of the learning activities should be done online, such as the submission of assignments, and technologies should be used as part of the students' learning experience. Regarding the latter, lecturers should provide students with opportunities to do projects, use digital tools to collect information, create presentations and so on. E-tutor and technical support for students should form part 
of student success initiatives. As part of the blended learning model, F2F tutors should either double up as e-tutors, or e-tutors should be appointed to augment the support provided by F2F tutors. Technical support should readily be provided to students who may encounter technical problems in using their laptops or need to install software to be able to learn.

- The establishment of a call centre to respond to or redirect student queries may alleviate most of the burden felt by support staff and lecturers in the Faculties. The call centre is the first point of entry into the university and directs queries to the relevant departments. The centre deals with faculty-specific issues, academic support and psychosocial support, thus enriching students' learning experiences.

- Many historically disadvantaged universities were confronted with staff and students who lacked the tools of trade to work effectively online. Universities, especially disadvantaged institutions, should budget for laptops (and associated maintenance and insurance costs) for staff as part of their recruitment processes. As far as students are concerned, arrangements are underway to ensure that part of the government National Financial Aid Scheme (NFAS) bursary allocated for the purchase of books, for example, goes towards the provisioning of laptops.

- Technical task teams should be established to help develop, refine policies, procedures and standards on online learning. These teams should comprise both academic and support staff.

- Providing training to staff to teach online is pivotal to the success of online learning. Universities should forge partnerships with online universities both nationally and internationally and encourage academics to register for programmes on online teaching as part of their blended learning/online learning strategy and staff development.

- The importance of establishing academic experts in the Faculties is central to the success of online teaching. The experts provide assistance to lecturers struggling with online teaching and ameliorate the stresses associated with online learning. Most universities do not have enough human resources to provide training for both students and staff. Academic experts therefore provide this intervention to their own peers. These teams also collaborate across Faculties and share best practices which helps with the buy-in and provides staff with an opportunity to experiment with different platforms.

- Universities in far-flung areas have experienced connectivity challenges. In addition, students from these areas also struggle with internet connectivity at home. Consequently, asynchronous instruction, including the recording of short videos for students, should be the primary mode of teaching and learning. Social media platforms such as WhatsApp should be used as additional resources.

\section{Conclusion}

Although pandemic conditions may present challenges for education, they also afford higher education institutions an opportunity to craft long-term solutions. Moving forward, implementation of well-thought-out blended learning approaches will continue to leverage on the use of technologies and student and staff support frameworks as part 
of the education eco-system. Research and reflexive teaching are central in refining and developing strategies for online learning. Data analytics and monitoring and evaluation strategies are important interventions that will guarantee long-term solutions. While blended learning is the way of the future, we are aware that is poses many other challenges that will become evident in the immediate future. These challenges will likely relate to the issue of pedagogy, staff and student capacitation, the realities of student under-digitisation etc., which are challenges we hope to address in future submissions resulting from the WSU pilot project.

In this article we have discussed ERT as an emergency resource during times of disruption such as the Covid-19 pandemic and highlighted the dynamics and challenges engendered by this model of teaching and learning. Secondly, we have argued that our context and education policies present additional problems that militate against the adoption of online approaches to teaching and learning. In the final instance, we have offered a framework that is best suited to the WSU context and could be used during and after the lockdown. The framework is drawn from our experience of the pilot project implemented to introduce online learning in response to the national lockdown resulting from the Covid-19 pandemic working with students who are readily able to access online learning, students with intermittent access to online facilities and students who cannot access online education.

\section{Acknowledgements}

We would like to acknowledge the comments we received from the journal's peer reviewers and editors which helped improve consecutive versions of this article.

\section{Research Ethics}

This research is based on reflections from participant observation in a pilot project and document analysis. While no ethics clearance was sought for the study, informed consent was obtained directly from participants through completion of informed consent forms.

\section{Conflict of Interest}

The authors have been personally involved in the practice described and analysed in this article and declare no conflict of interest.

\section{Funding}

No funding has been received specifically for this study. The authors would like to acknowledge the time and resources and support availed by their university to conduct and write up this study.

\section{References}

Badat, S. (2010). The Challenges of Transformation in Higher Education and Training Institutions in South Africa. Development Bank of Southern Africa.

CHE (Council on Higher Education) (2020). Quality assurance guidelines for emergency remote teaching $\mathcal{E}$ learning and assessment during the Covid-19 pandemic. South Africa: $\mathrm{CHE}$. 
Hodges, C., Moore, S., Lockee, B.,Trust,T. \& Bond, M. (2020, April 27). The difference between emergency remote teaching and online learning. Educause Review. https://er.educause.edu/articles/2020/3/ the-difference-between-emergency-remote-teaching-and-online-learning

Lee, E.C., Whitehead,A.L., Jacques, R.M. \& Julious, S.A. (2014). The statistical interpretation of pilot trials: Should significance thresholds be reconsidered? BMC Medical Research Methodology, 14(41), 1-8. https://doi.org/10.1186/1471-2288-14-41

Leibowitz, B., Bozalek, V., Farmer, J., Garraway, J., Herman, N., Jawitz, J., Mc Millan, W., Mistri, G., Ndebele, C., Nkonki,V., Quinn, L.,Van der Merwe, S.,Vorster, J. \& Winberg, C. (2017). Collaborative Research in Contexts of Inequality: The Role of Social Reflexivity. Higher Education, 74, 65-80. https://doi.org/10.1007/s10734-016-0029-5

Leibowitz, B., Bozalek, V., James, G., Nicoline, H., Jeff, J., Muhuro, P., Ndebele, C., Quinn, L., Van Schalkwyk, S.,Vorster, J-A. \& Winberg, C. (2017). Learning to teach in higher education: An investigation into the influences of institutional context on the professional learning of academics in their role as teachers. Pretoria: Council on Higher Education.

Li, H. \& Masters, J. (2009). Editorial: E-learning and knowledge management in the early years: Where are we and where should we go. Knowledge Management \& E-Learning: An International Journal, 1(4), 245-250. https://doi.org/10.34105/j.kmel.2009.01.017

Luaran, J.E., Samsuri, N.N., Nadzri, F.A. \& Baharen, K. (2014). A study on the student's perspective on the effectivenees of using e-learning. Procedia-Social and Behavioural Sciences, 123, 139-144. https://doi. org/10.1016/j.sbspro.2014.01.1407

Mbodila, M., Ndebele, C. \& Muhandji, M. (2019). Assessing options for ICTs integration in the classroom at a rural based South African university. Journal of Gender, Information and Development in Africa (JGIDA), 8(2), 37-58. https://doi.org/10.31920/2050-4284/2019/8n2a3

Morgan, H. (2020). Best practices for implementing remote learning during a pandemic: The Clearing House. A Journal of Educational Strategies, Issues \& Ideas, 93(3), 135-141. https://doi.org/10.1080/000 98655.2020.1751480

Murphy, M.P.A. (2020). Covid-19 and emergency eLearning: Consequences of the securitization of higher education for post-pandemic pedagogy. Contemporary Security Policy, 41(3), 492-505. https://doi.org/ 10.1080/13523260.2020.1761749

Ndebele, C., Muhuro, P. \& Nkonki, V. (2016). Rurality and the professional development of university teachers South African Journal of Higher Education, 30(6), 127-145. https://doi.org/10.20853/30-6-728

Ramakrisnan, P., Yahya, Y., Hasrol, M.N.H. \& Aziz, A.A. (2012). Blended learning: A suitable framework for e-learning in higher education. Social and Behavioural Sciences, 67, 513-526. https://doi. org/10.1016/j.sbspro.2012.11.356

Roddy, C. \& Lodge, J. (2017). Applying best practice online learning, teaching, and support to intensive online environment: An integrative review. Frontiers in Education, 2(59), 1-10. https://doi.org/10.33 89/feduc.2017.00059

Sangra, A., Vlachopoulos, D. \& Cabrera, M. (2012). Building an inclusive definition of e-learning: An approach to the conceptual framework. The International Review of Research in Open and Distributed Learning, 13(2), 145-159. https://doi.org/10.19173/irrodl.v13i2.1161

Samir Abou El-Seoud, M., Taj-Eddin, I.A.T.F,, Seddiek, N., El-Khouly, M.M. \& Nosseir, A. (2014). E-learning and student's motivation:A research study on the effect of e-learning on higher education. International Journal of Emerging Technologies in Learning (IJET), 20-26. https://doi.org/10.3991/ijet. v9i4.3465

Shamase, N. (2016, January 14). Helping others is a no-brainer. Mail \& Guardian. 
Subedi, S., Nayaju, S., Subedi, S., Shah, S.K. \& Shah,J.M. (2020). The impact of e-learning during Covid-19 pandemic among nursing students and teachers of Nepal. International Journal of Science \& Healthcare Research, 5(3), 68-76.

Tanis, C.J. (2020). The seven principles of online learning: Feedback from Faculty and alumni on its importance for teaching and learning. Research in Teaching Technology, 28(2319), 1-25. https://doi. org/10.25304/rlt.v28.2319

University of the People (2020). Emergency remote teaching Vs online learning: A comparison. https://www. uopeople.edu/blog/emergency-remote-teaching-vs-online-learning

Vale, P. (2016, January 14). Say it in plain African Language. Mail \& Guardian.

Welman, J.C. \& Kruger, F. (2001). Research methodology for the business and administrative sciences. Oxford University Press.

Williamson, B., Eynon, R. \& Potter, J. (2020). Pandemic politics, pedagogies and practices: digital technologies and distance education during coronavirus emergency. Learning. Media and Technology 45(2), 107-114. https://doi.org/10.1080/17439884.2020.1761641

WSU (Walter Sisulu University) (2020a). WSU Draft 2020-30 Strategic Plan. Umtata: WSU.

WSU (Walter Sisulu University) (2020d). WSU Term 2 Quarterly Report 2020. Umtata: WSU.

\section{How to cite:}

Songca, R.N., Ndebele, C. \& Mbodila, M. (2021). Mitigating the Implications of Covid-19 on the Academic Project at Walt er Sisulu University in South Africa: A Proposed Framework for Emergency Remote Teaching and Learning. Journal of Student Affairs in Africa, 9(1), 41-60. DOI: $10.24085 /$ jsaa.v9i1.1427 